\title{
LUT
}

Lappeenranta

University of Technology

\section{Effect of Converter Topology on the Specific Energy Consumption of Alkaline Water Electrolyzers}

Koponen Joonas, Ruuskanen Vesa, Kosonen Antti, Niemelä Markku, Ahola Jero

This is a Final draft version of a publication

published by IEEE

in IEEE Transactions on Power Electronics

DOI: $\quad$ 10.1109/TPEL.2018.2876636

Copyright of the original publication: (c) 2018 IEEE

Please cite the publication as follows:

Koponen, J., Ruuskanen, V., Kosonen, A., Niemelä, M., Ahola, J. (2018). Effect of Converter Topology on the Specific Energy Consumption of Alkaline Water Electrolyzers. IEEE Transactions on Power Electronics. DOI: 10.1109/TPEL.2018.2876636 


\title{
Effect of Converter Topology on the Specific
}

\section{Energy Consumption of Alkaline Water Electrolyzers}

Joonas Koponen, Vesa Ruuskanen, Antti Kosonen, Markku Niemelä, and Jero Ahola

\begin{abstract}
Water electrolysis will be used to produce renewable hydrogen for energy storage and Power-to-X applications in the future renewable-energy-based energy systems. Therefore, the energy efficiency of hydrogen production will probably become a major issue. In this study, the effect of practical supply power converters on the specific energy consumption of MW-scale alkaline electrolyzers is studied and compared with an ideal DC power supply. The current quality and the stack specific energy consumption are studied in the case of traditional thyristor rectifiers and a transistor-based converter. The stack specific energy consumption is analyzed based on the simulated current waveforms and the electrical equivalent circuit of the electrolyzer stack. It is found that the transistor-based converter offers up to $14 \%$ lower electrolyzer stack specific energy consumption than the 6-pulse thyristor rectifier and up to 9.2\% lower electrolyzer stack specific energy consumption than the 12-pulse thyristor rectifier as the current varies between $5000 \mathrm{~A}$ and $1000 \mathrm{~A}$. The simulated change in the stack specific energy consumption of the MW-scale alkaline water electrolyzer outweighs the losses occurring in the rectifiers. Further, selection of the AC voltage level may have a more adverse effect on the stack specific energy consumption with the thyristor rectifier topologies compared with the transistor-based topologies.
\end{abstract}

\section{INTRODUCTION}

Water electrolyzers may be the main electricity consumers in the future as the whole energy sector has to be based on renewable energy sources [1]. Renewable hydrogen is needed to produce carbon-neutral fuels for transportation and seasonal energy storages, as well as raw materials for the chemical and steel industries [2]-[6]. Therefore, optimization of the specific energy consumption of water electrolyzers is essential for future energy systems. Water electrolysis has been identified as the main cost contributor to the capital expenditure (CAPEX) of Power-to-Gas systems [2], [7], [8]. The CAPEX of the water electrolyzer supply converter is approximately $15 \%$ of the CAPEX of the electrolyzer system for both alkaline and proton exchange membrane (PEM) water electrolyzer technologies [9].

J. Koponen, V. Ruuskanen, A. Kosonen, M. Niemelä, and J. Ahola are with the LUT School of Energy Systems, Lappeenranta University of Technology, Lappeenranta, 53850 Finland (e-mail: joonas.k.koponen@lut.fi; vesa.ruuskanen@lut.fi; antti.kosonen@lut.fi; markku.niemela@lut.fi; jero.ahola@lut.fi). 
In Power-to-X systems, where electrical energy is converted into other forms of energy, the water electrolyzer stack is the main energy consumer, and hydrogen is the main energy carrier in the end product. The hydrogen production rate of a water electrolyzer is directly proportional to the mean value of the DC current supplied to the electrodes, and thus, the cost of electricity is the main contributor to the cost of electrolytic hydrogen gas. State-of-the-art, commercial alkaline and PEM water electrolyzers can reach voltage efficiencies up to 82\% [10], when compared with the minimum energy requirement defined by the higher heating value of hydrogen gas, $39.4 \mathrm{~kW} \mathrm{~h} \mathrm{~kg}^{-1}$. However, owing to the requirement for high DC currents, the rectifiers in conventional industrial water electrolyzers are typically based on thyristors and diodes [11]. Switching according to the line frequency generates harmonics to the supplied current and voltage causing additional heat losses in the water electrolysis process [12], [13]. Application of more modern power electronic converters could be beneficial, but would require modular conversion structures to share the supplied currents among suitable levels for semiconductors using forced commutation, such as an insulated-gate bipolar transistor (IGBT). The optimization of the electrolyzer stack losses outweighs the losses in the power electronic converters as the rectifiers used in conventional water electrolysis systems can reach efficiencies exceeding $98 \%$.

Possible effects of inverter current ripple on PEM fuel cell operation have been introduced in [14]. Low-frequency current ripple was found to have an impact on the performance, efficiency, and lifetime of a solid oxide fuel cell in [15]. However, the fuel cell inverters-typically preceded by a DC-DC boost converter if voltage level increase is required before the inverter [16]-are typically transistor-based topologies with generally lower amplitude current ripple compared to the DC current quality seen in water electrolyzers supplied by traditional thyristor rectifiers [17]. For fuel cells, the switching frequency has been recommended to be greater than $1.25 \mathrm{kHz}$ and the fuel cell current ripple lower than 5\% to prevent cell operation disturbance [17]. The fuel cell inverter current quality and sizing of the filter capacitor are discussed in [18]. The load transients and current ripple has been shown to have a significant effect on the area specific resistance (ASR) degradation of the planar solid oxide fuel cell [19]. However, the effect of current ripple on electrolytic cell lifetime is still a key research question for water electrolyzers [9], [20].

The effects of power conditioning on the specific energy consumption of water electrolyzers were introduced in [11], [12], where one thyristor-based topology was compared with a transistor-based one. The comparison was conducted by analyzing the resulting specific energy consumptions for a $5 \mathrm{~kW}$ alkaline water electrolyzer. $A$ labscale alkaline water electrolyzer was analyzed in [21], where steady DC current resulted in minimized cell efficiency loss.

The power quality of the AC and DC sides of a thyristor rectifier with a distribution static compensator (DSTATCOM) was analyzed for example in [22], but the effect of power quality on the load behavior was not considered. A DC chopper was introduced for electrochemical applications in [23]. The chopper rectifier was stated to have a higher efficiency than a thyristor-based rectifier in the whole operating range despite the lowest output voltages. The three-phase chopper with a diode rectifier was shown to have a higher efficiency than a thyristor bridge with a DSTATCOM [24]. Efforts have been made to apply IGBTs to specific high-current rectification applications [25], [26]. Yet, thyristor topologies are the traditional, most common solution for high-current, high- 
power applications [24]-[26].

In this paper, the effect of power quality on the energy consumption of a MW-scale alkaline water electrolyzer stack is analyzed using simulation tools. A simplified model for the MW-scale water electrolyzer is established based on the measured performance of a small-scale alkaline water electrolyzer. The rectifier topologies selected for analysis are: 1) a 6-pulse thyristor rectifier, 2) a 12-pulse thyristor rectifier, and 3) a 6-pulse diode bridge followed by an IGBT-based chopper. The transistor-based topology is selected to represent the more modern, practical alternative to the typical thyristor rectifiers [24], [27]. The current quality of the transistor-based topology could be further improved by reselecting the switching frequency and resizing the reactive components. However, this paper concentrates on the main differences between the thyristor and transistor topologies in the alkaline water electrolyzer supply converters, and the filter design is not considered.

The main contributions of this paper are: 1. The current and voltage waveforms of the MW-scale alkaline electrolyzer stack are simulated in the case of thyristor rectifiers and the transistor-based chopper power supply converter. 2. The resulting water electrolyzer stack specific energy consumptions as a function of load current are compared with a pure DC supply. 3. The effect of the AC voltage level selection on the stack specific energy consumption is studied. 4. The effect of the converter topology on the water electrolyzer controllability and implications of stack degradation for the AC voltage level selection are discussed.

This paper is organized as follows. Section II introduces the basics of the electrochemistry in water electrolysis processes and describes the simplified electrical model of the MW-scale alkaline electrolyzer stack. The power quality and specific energy consumption of the alkaline electrolyzer with 6- and 12-pulse thyristor rectifiers and a transistor chopper-based converter are studied in Section III. Section IV concludes the paper.

\section{Method of AnAlysis}

The hydrogen production rate $\left(\mathrm{mol} \mathrm{s}^{-1}\right)$ of a single electrolytic cell is linearly proportional to the current

$$
f_{\mathrm{H}_{2}}=\eta_{\mathrm{F}} \frac{i_{\text {cell }} A_{\text {cell }}}{z F}
$$

where $f_{H_{2}}$ is the hydrogen production rate $\left(\mathrm{mols}^{-1}\right), z$ the number of moles of electrons transferred in the reaction (for hydrogen, $z=2), F$ the Faraday constant $\left(9.6485 \times 10^{4} \mathrm{C} \mathrm{mol}^{-1}\right), i_{\text {cell }}$ the current density $\left(\mathrm{A} \mathrm{cm}{ }^{-2}\right), A_{\text {cell }}$ the effective cell area $\left(\mathrm{cm}^{2}\right)$, and $\eta_{\mathrm{F}}$ the Faraday efficiency, also known as the current efficiency.

Experimental data are required to model the selected water electrolysis processes as shown in [13], [28], [29]. The electrolytic cell voltage is a sum of the reversible voltage and additional overvoltages appearing in the electrolytic cell

$$
U_{\text {cell }}=U_{\text {rev }}+U_{\text {ohm }}+U_{\text {act }}+U_{\text {con }}
$$

where $U_{\text {cell }}$ is the cell voltage, $U_{\text {rev }}$ the reversible voltage, which is the lowest voltage required for the water decomposition to occur, $U_{\mathrm{ohm}}$ the overvoltage caused by ohmic losses in the cell elements, $U_{\text {act }}$ the activation overvoltage produced by electrode kinetics, and $U_{\text {con }}$ the concentration overvoltage resulting from mass transport 
processes [30]. The principle of the bipolar electrolyzer stack with series-connected cells and the actual stack of the studied alkaline electrolyzer are illustrated in Fig. I.

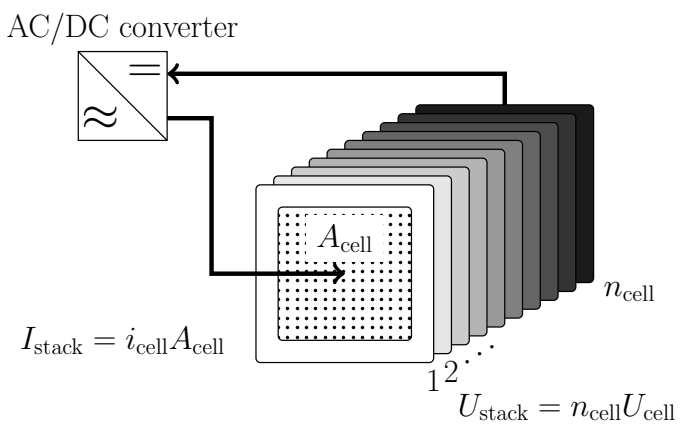

(a)

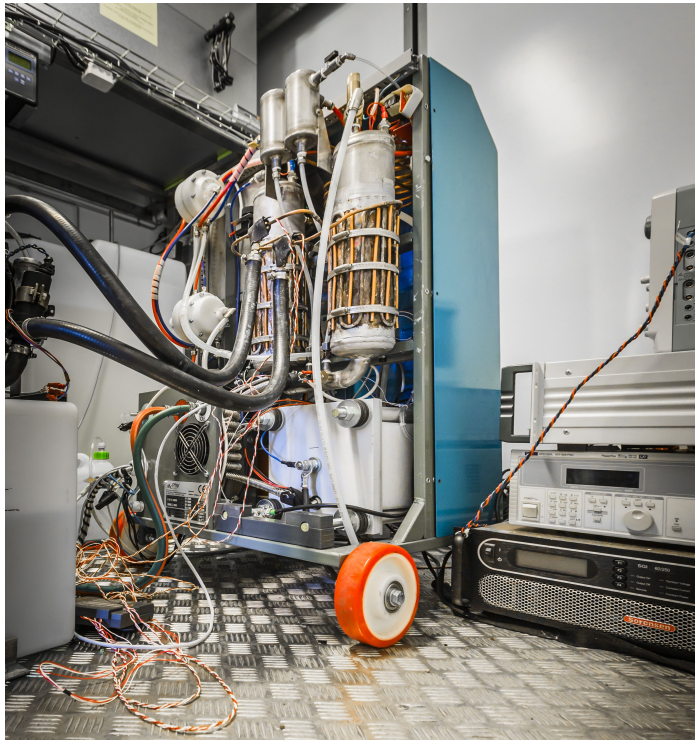

(b)

Fig. 1. Operating principle of the bipolar electrolyzer stack with series-connected cells and the actual electrolyzer stack of the Baby McPhy alkaline water electrolyzer; the nominal hydrogen production rate of the electrolyzer is $0.4 \mathrm{~N} \mathrm{~m}^{3} \mathrm{~h}^{-1}$ with the electrical power of $2.8 \mathrm{~kW}$. (a) Principle of the DC power supply of the bipolar electrolyzer stack. (b) Electrolyzer stack of the Baby McPhy alkaline water electrolyzer with 30 cells connected in series.

In this study, a simplified electrical model of the stack is used for the simulation. The stack is assumed to operate under constant temperature and pressure. Therefore, the reversible voltage is assumed to be constant and the overpotential caused by the stack current to be linearly dependent on the current amplitude

$$
U_{\text {stack }}=U_{\text {rev,stack }}+R I_{\text {stack }}
$$

where $U_{\text {rev,stack }}$ is the stack reversible voltage $(\mathrm{V}), R$ the equivalent resistance of the cell $(\Omega)$, and $I_{\text {stack }}$ the stack current (A). The measured voltage and current waveforms of the alkaline electrolyzer in Fig. 1b with 30 cells connected in series are presented in Fig. 2a. As there seems to be no phase shift between the voltage and the current despite the relatively high $(1 \mathrm{kHz}) \mathrm{AC}$ ripple frequency, the stack impedance can be assumed to be purely resistive. Fig. $2 \mathrm{~b}$ depicts the measured voltage as a function of current with the estimated voltage with a reversible voltage of $55.65 \mathrm{~V}$ and a stack equivalent resistance of $277 \mathrm{~m} \Omega$.

Solanki et al. [22] used a similar kind of linear voltage equation for an MW-scale electrolyzer with $U_{\text {rev,stack }}$ values from $142 \mathrm{~V}$ to $150 \mathrm{~V}$ and $R$ values from $4.8 \mathrm{~m} \Omega$ to $15.4 \mathrm{~m} \Omega$. In this study, the values of the Baby McPhy alkaline electrolyzer can be scaled to the MW range by multiplying the voltage by a factor of three, as a result of which the total number of series-connected cells is 90 with the nominal voltage of $U_{\text {stack }}=200 \mathrm{~V}$. The current, linearly proportional to the active cell area (see Fig. 1a), is scaled by a factor of one hundred and the nominal 


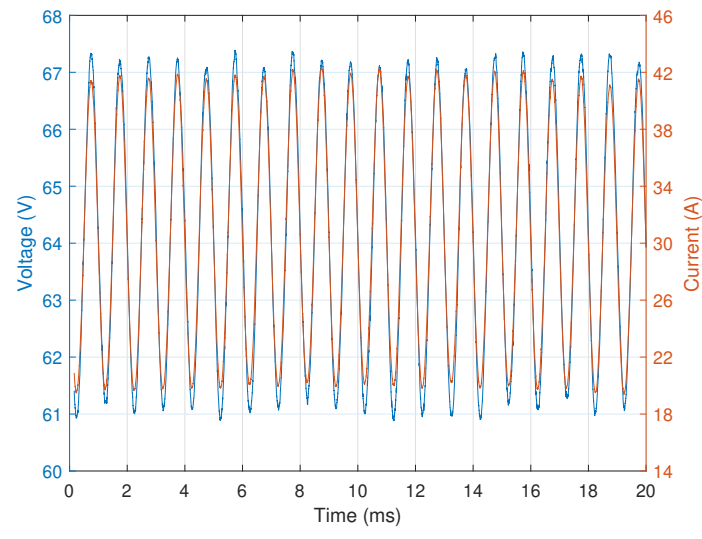

(a)

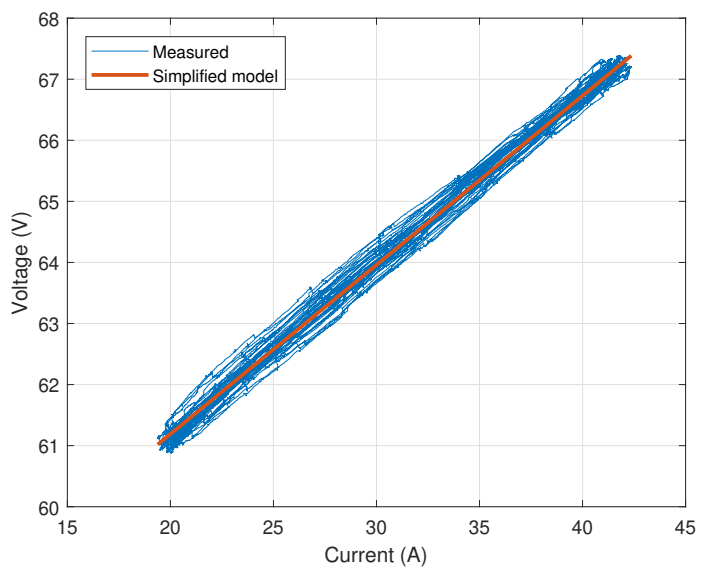

(b)

Fig. 2. Measured current and voltage waveforms of the Baby McPhy alkaline water electrolyzer. The measured voltage as a function of current is compared with a simplified model. (a) Voltage and current waveforms. (b) Voltage as a function of current.

current is chosen to be $I_{\text {stack }}=5000 \mathrm{~A}$. Therefore, the voltage equation parameters are selected to be $U_{\text {rev,stack }}=$ $150 \mathrm{~V}$ and $R=10 \mathrm{~m} \Omega$. The key electrical parameters of the commercial small-scale alkaline water electrolyzer and the scaled water electrolyzer used in the simulations are collected in Table I.

TABLE I

Electrical Parameters of the Measured McPhy BabyPIEL Alkaline Water Electrolyzer and the Scaled $1 \mathrm{MW}$ Industrial Alkaline Water Electrolyzer.

\begin{tabular}{lcccccc}
\hline \hline & $I_{\text {stack }}(\mathrm{A})$ & $U_{\text {stack }}(\mathrm{V})$ & $P_{\text {stack }}(\mathrm{kW})$ & $n_{\text {cell }}(-)$ & $R(\mathrm{~m} \Omega)$ & $U_{\text {rev,stack }}(\mathrm{V})$ \\
\hline BabyPIEL & 35 & 65 & 2.8 & 30 & 277 & 55.65 \\
Scaled electrolyzer & 5000 & 200 & 1000 & 90 & 10 & 150 \\
\hline \hline
\end{tabular}

The voltage and current waveforms of the electrolyzer stack supplied with various power supply converters are simulated using the Simscape environment in the MATLAB Simulink software. The electrical power of the stack is defined based on the stack current and voltage as a function of time. The hydrogen production is calculated based on the current with (1) neglecting the effect of the Faraday efficiency, as a result of which the average hydrogen production is only a function of current DC value. However, the Faraday efficiency has been suggested to be a function of current density in constant DC current operation in [31], where the measured Faraday efficiency varied as a nonlinear function of current density in the range of $28 \%-99 \%$. Further investigations are required to explicate the instantaneous Faraday efficiency of water electrolyzers on the millisecond timescale. The specific energy consumption $E_{\mathrm{s}}$ of an electrolysis process can be obtained from

$$
E_{\mathrm{s}}=\frac{\int_{0}^{t} I_{\text {stack }} U_{\text {stack }} d t}{\int_{0}^{t} f_{\mathrm{H}_{2}} d t} .
$$


The higher heating value (HHV) is the minimum energy required to produce hydrogen gas with a thermoneutral process. The per mass unit HHV of hydrogen gas is $39.4 \mathrm{~kW} \mathrm{~h} \mathrm{~kg}^{-1}$, which can be assumed to represent the energy consumption of the process with a $100 \%$ efficiency.

\section{RESULTS}

The output current and voltage quality of the 6-pulse and 12-pulse thyristor rectifiers and the transistor-based converter is studied. The specific energy consumption of the electrolyzer is analyzed as a function of DC current in the range from $1000 \mathrm{~A}$ to $5000 \mathrm{~A}$ level by setting the thyristor firing angle and the transistor pulse width with a PI controller in Simulink. Further, the effect of the AC voltage level on the electrolyzer energy efficiency is considered.

\section{A. 6-Pulse Thyristor Bridge}

A 6-pulse thyristor rectifier is connected to a three-phase voltage source and no filtering is used in either side of the rectifier bridge. The minimum RMS value of the main voltage of the supply grid $U_{\mathrm{AC}}$ is selected to be $150 \mathrm{~V}$ to achieve a current of $5000 \mathrm{~A}$ almost at the full voltage of the rectifier. The voltage and current waveforms with the currents of $1000 \mathrm{~A}$ and $5000 \mathrm{~A}$ are given in Fig. 3.

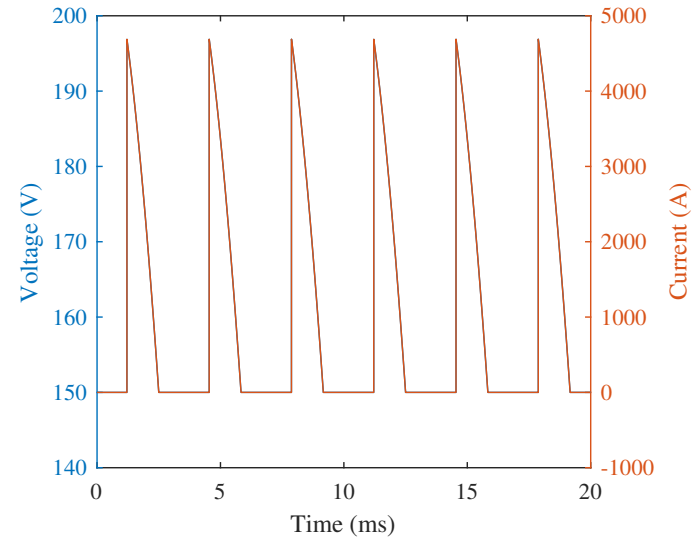

(a)

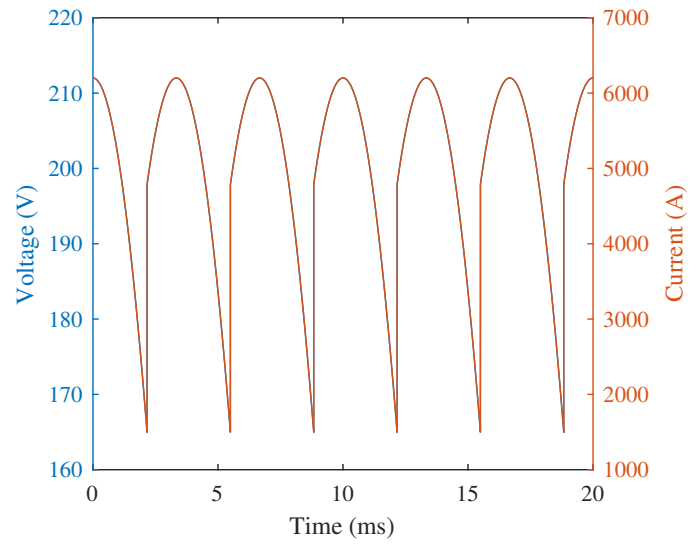

(b)

Fig. 3. Voltage and current waveforms of the 6-pulse rectifier at certain DC current levels, when $U_{A C}=150$ V. (a) $1000 \mathrm{~A}$. (b) $5000 \mathrm{~A}$.

The thyristor rectifier excites significant current ripple. At partial loads, the current momentarily reaches a zero value. The frequency components of the current are given as a function of current mean value at two different grid voltage values in Fig. 4.

It can be seen that the amplitude of the $300 \mathrm{~Hz}$ current ripple exceeds the current DC level at loads below $3000 \mathrm{~A}$. Further, the increased grid voltage leads to a higher firing angle of the thyristors and, thereby, higher current ripple values. The specific energy consumption of the electrolyzer supplied with the 6-pulse rectifier is compared with a pure DC supply in Fig. 5.

The current ripple excited by the thyristor bridge significantly increases the energy consumption of the electrolyzer stack. The effect of the power supply is emphasized at the lowest DC current levels and the highest grid voltage 


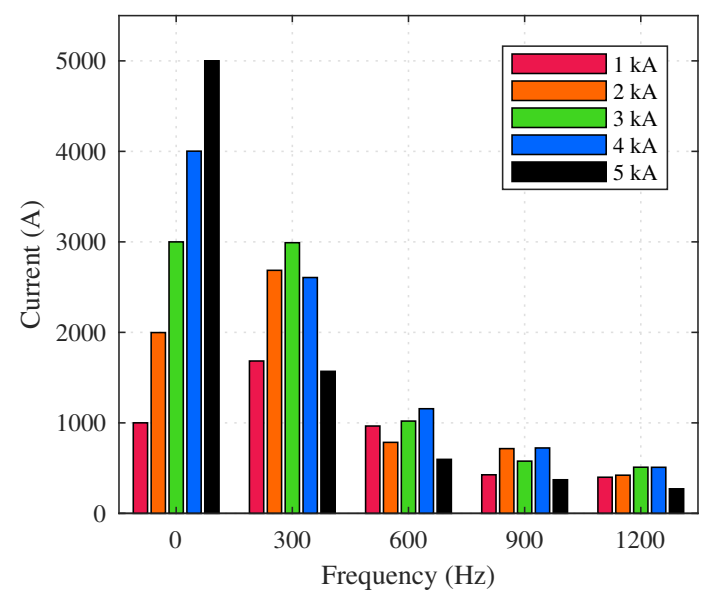

(a)

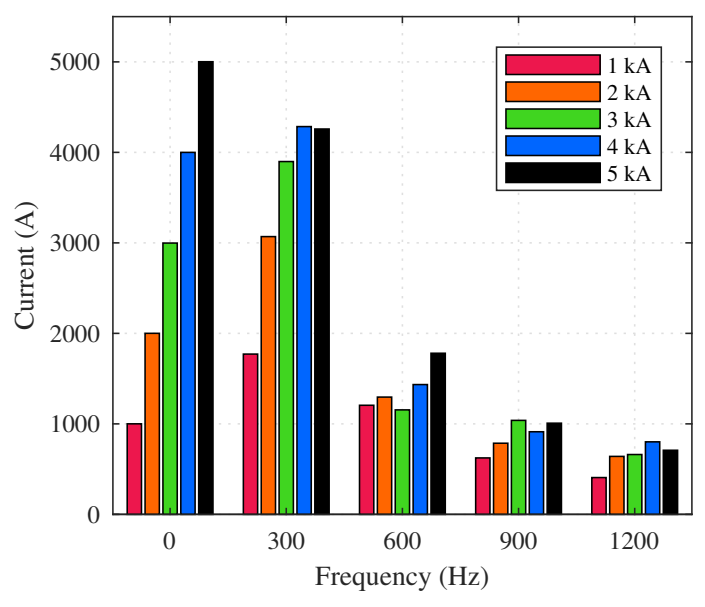

(b)

Fig. 4. Current frequency content with the 6-pulse rectifier at certain DC current levels. (a) $U_{A C}=150 \mathrm{~V}$. (b) $U_{A C}=175 \mathrm{~V}$.

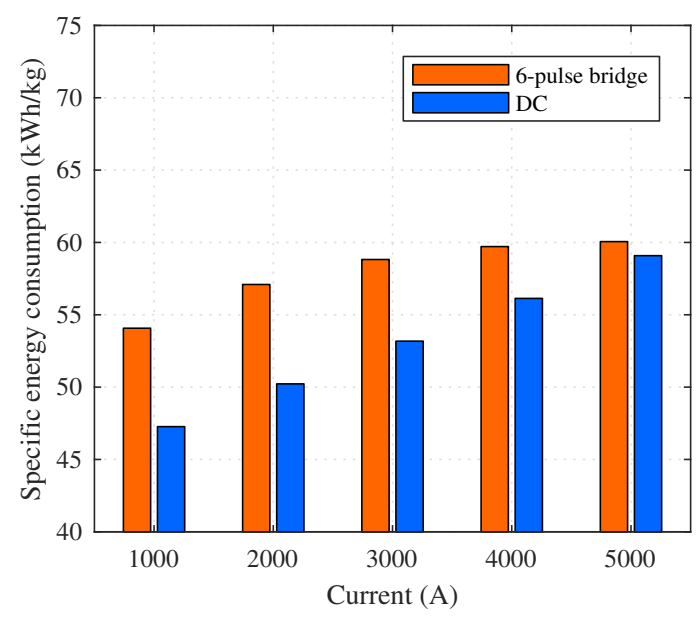

(a)

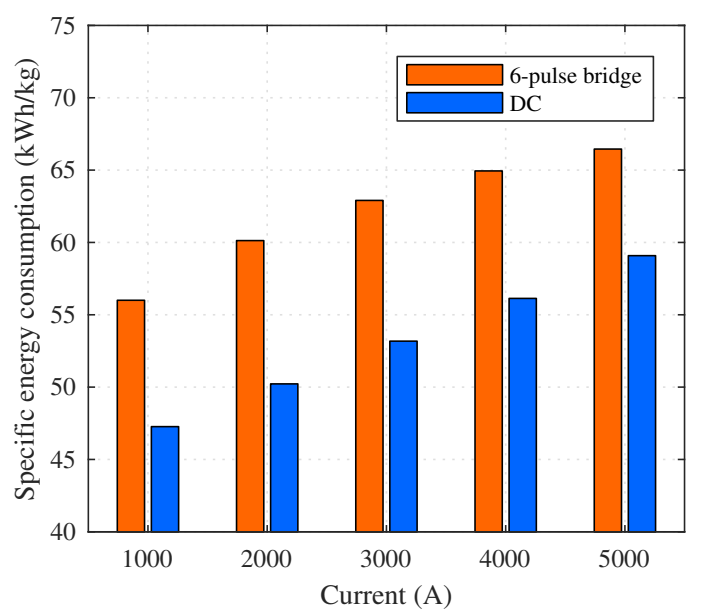

(b)

Fig. 5. Specific energy consumption of the electrolyzer supplied with the 6-pulse rectifier and pure DC at certain DC current levels. (a) $U_{A C}=150 \mathrm{~V}$. (b) $U_{A C}=175 \mathrm{~V}$.

levels. In the studied case, at the grid voltage of $150 \mathrm{~V}$, the energy consumption with the 6-pulse rectifier is $14.4 \%$ higher than with the pure DC supply at the partial load of $1000 \mathrm{~A}$ and $1.6 \%$ higher at the full load. At the grid voltage of $175 \mathrm{~V}$, the energy consumption with the 6-pulse rectifier is $18.5 \%$ higher than with the pure DC supply at the partial load of $1000 \mathrm{~A}$ and $12.5 \%$ higher at the full load. As the grid voltage level affects the required firing angle and the current waveform, the specific energy consumption with the 6-pulse bridge is given as a function of DC current level and grid voltage in Fig. 6.

Obviously, the DC current level is the main factor affecting the specific energy consumption. However, the effect of the supply AC voltage cannot be neglected either, but the voltage level must be matched with the maximum current of the electrolyzer at the zero firing angle of the thyristor bridge. 


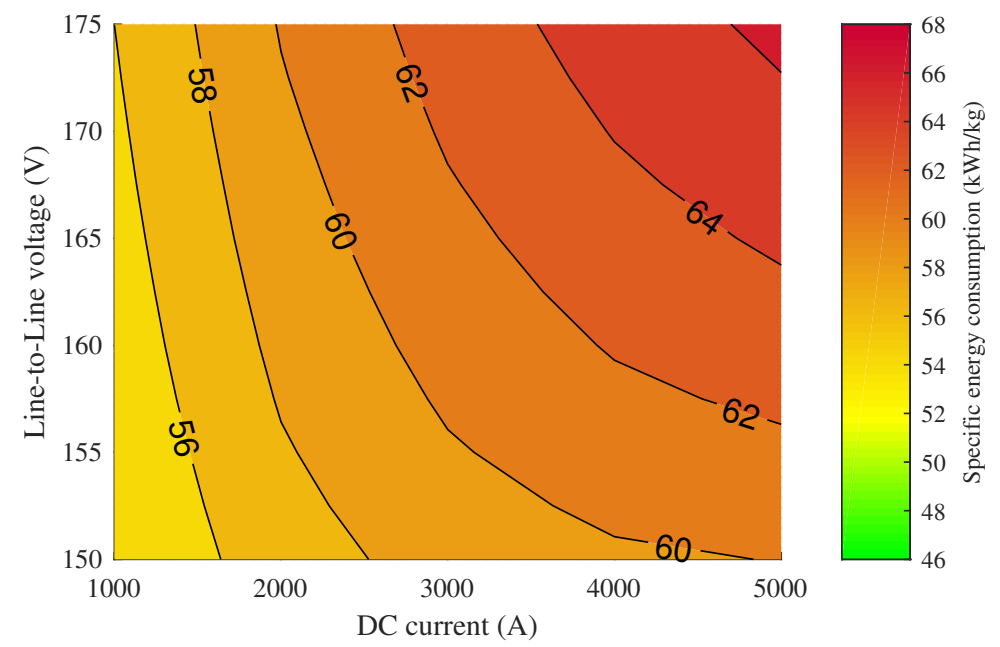

Fig. 6. Specific energy consumption of the electrolyzer as a function of DC current level and the line-to-line voltage of the 6-pulse rectifier input.

\section{B. 12-Pulse Thyristor Bridge}

A 12-pulse thyristor rectifier is implemented by connecting two 6-pulse rectifiers in series as shown for example in [22]. The AC supplies of the rectifiers are phase shifted by $30^{\circ}$ from each other. Further, the voltage amplitude of the AC supplies is scaled by a factor of $\frac{\sqrt{2}}{\sqrt{3}+1}$ to achieve the same DC voltage peak values as in the case of the 6-pulse rectifier. The voltage and current waveforms with the currents of $1000 \mathrm{~A}$ and $5000 \mathrm{~A}$ are shown in Fig. 7.

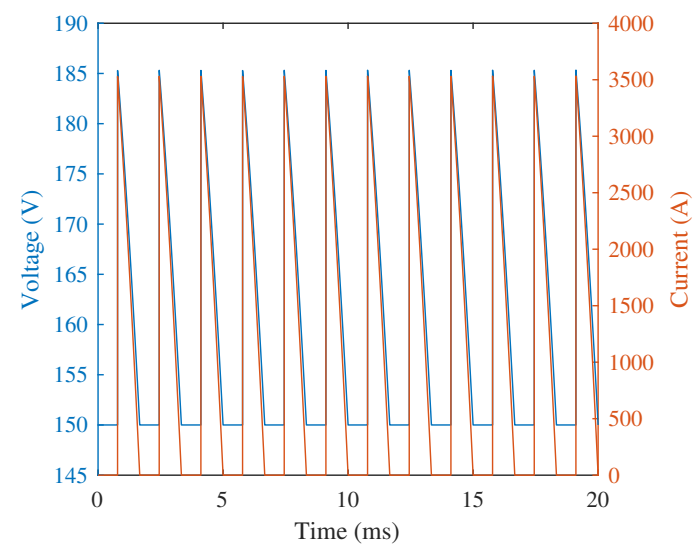

(a)

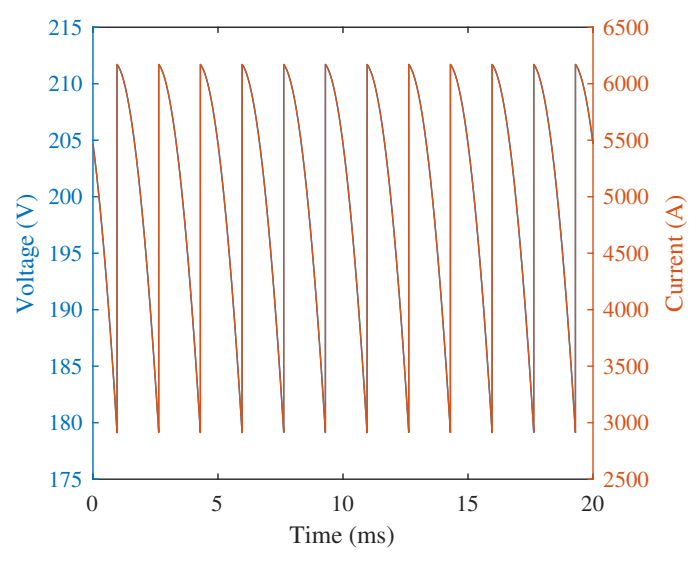

(b)

Fig. 7. Voltage and current waveforms of the 12-pulse rectifier at certain DC current levels, when $U_{A C}=150$ V. (a) $1000 \mathrm{~A}$. (b) $5000 \mathrm{~A}$.

The voltage and current ripple are significantly lower with the 12-pulse rectifier than with the 6-pulse rectifier. The frequency components of the current are given as a function of current mean value at two different grid voltage values in Fig. 8.

The dominating harmonic component at $600 \mathrm{~Hz}$ has significantly lower amplitudes than the $300 \mathrm{~Hz}$ component 


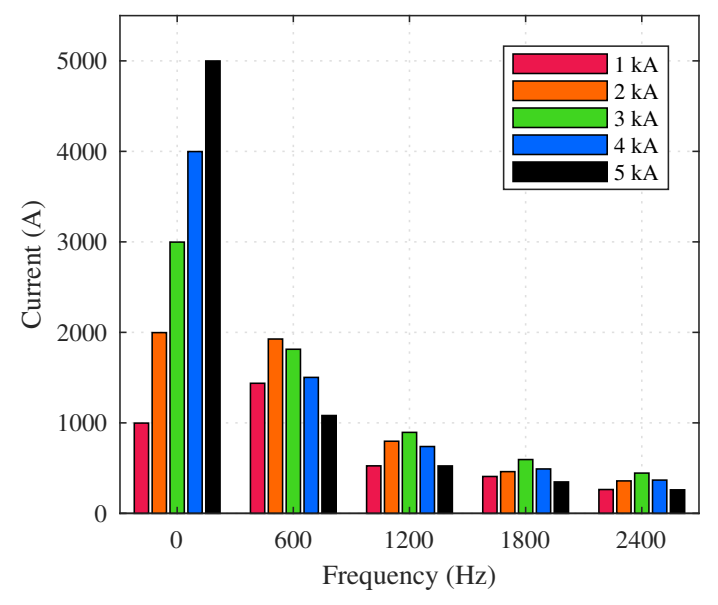

(a)

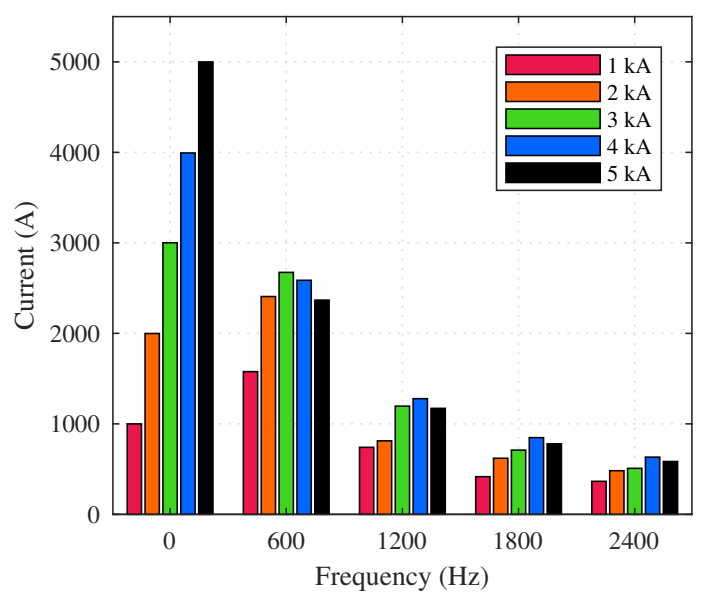

(b)

Fig. 8. Current frequency content with the 12-pulse rectifier at certain DC current levels. (a) $U_{A C}=150 \mathrm{~V}$. (b) $U_{A C}=175 \mathrm{~V}$.

in the case of the 6-pulse rectifier. The specific energy consumption of the electrolyzer supplied with the 12-pulse rectifier is compared with a pure DC supply in Fig. 9.

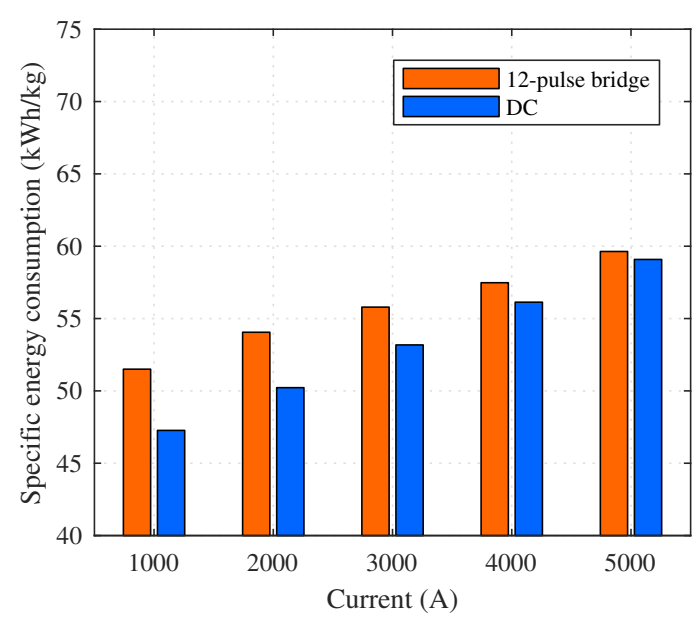

(a)

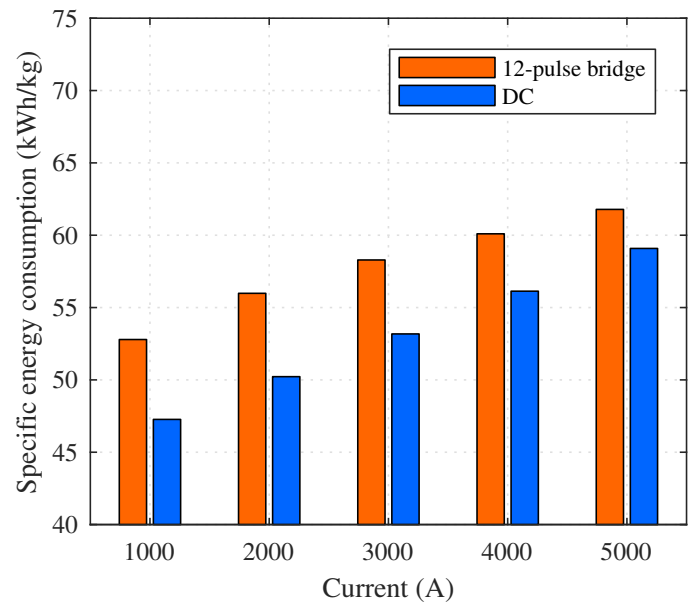

(b)

Fig. 9. Specific energy consumption of the electrolyzer supplied with the 12-pulse rectifier and pure DC at certain DC current levels. (a) $U_{A C}=150 \mathrm{~V}$. (b) $U_{A C}=175 \mathrm{~V}$.

The 12-pulse rectifier offers a better efficiency than the 6-pulse rectifier especially at partial loads around 50\% of the nominal current. In the studied case, at the grid voltage of $150 \mathrm{~V}$, the energy consumption with the 12-pulse rectifier is $9.0 \%$ higher than with the pure DC supply at the partial load of $1000 \mathrm{~A}$ and $0.9 \%$ higher at the full load. At the grid voltage of $175 \mathrm{~V}$, the energy consumption with the 12-pulse rectifier is $11.7 \%$ higher than with the pure DC supply at the partial load of $1000 \mathrm{~A}$ and $4.6 \%$ higher at the full load. As the grid voltage level highly affects the energy consumption also in the case of the 12-pulse rectifier, the specific energy consumption with the 
12-pulse bridge is presented as a function of DC current level and grid voltage in Fig. 10.

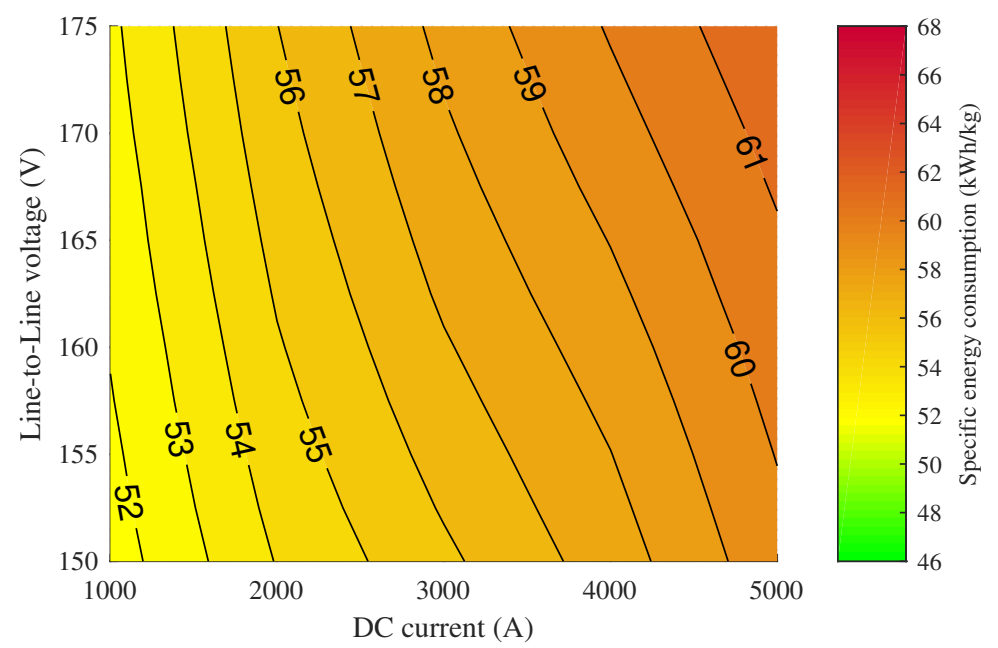

Fig. 10. Specific energy consumption of the electrolyzer as a function of DC current level and the line-to-line voltage of the 12-pulse rectifier input.

The 12-pulse rectifier offers a better efficiency than the 6-pulse rectifier over the whole operating range. However, it is pointed out that the losses of the rectifier itself are higher in the case of the 12-pulse rectifier as the current must flow through two 6-pulse rectifiers connected in series.

\section{Transistor-Based Topology}

A simple single leg step-down DC/DC converter is selected to study the characteristics of transistor-based forced commutation power supply topologies. A three-legged transistor topology is depicted in [24]. In this study, the DC/DC converter is supplied by a 6-pulse rectifier instead of the 12-pulse rectifier common in the literature. A capacitor of $1 \mathrm{mF}$ is used to stabilize the DC link voltage. In [24] there are $96 \mu \mathrm{H}$ inductors in each of the three output legs of the converter together with an output filtering capacitor. In this study, no capacitor is applied and a single $32 \mu \mathrm{H}$ inductor is used as an output filter. Further, the switching frequency of the transistor is selected to be $1 \mathrm{kHz}$. The voltage and current waveforms with the currents of $1000 \mathrm{~A}$ and $5000 \mathrm{~A}$ are shown in Fig. 11.

The effect of switching frequency is clearly seen at the partial load as the grid-excited pulsation of the DC link voltage is emphasized at the full load. The frequency components of the current are given as a function current mean value at two different grid voltage values in Fig. 12. The ripple amplitudes are far lower in the case of the transistor-based converter than with the thyristor rectifiers. The specific energy consumption of the electrolyzer supplied with the forced commutation rectifier is compared with the pure DC supply in Fig. 13.

The efficiency of the transistor converter-fed electrolyzer stack is only slightly higher than with the pure DC supply at all loads. Further, also the effect of the grid voltage on the electrolyzer stack efficiency is small. At the grid voltage of $150 \mathrm{~V}$, the energy consumption with the transistor converter is only $0.6 \%$ higher than with the pure DC supply at the partial load of $1000 \mathrm{~A}$ and $0.02 \%$ higher at the full load. At the grid voltage of $175 \mathrm{~V}$, the energy 


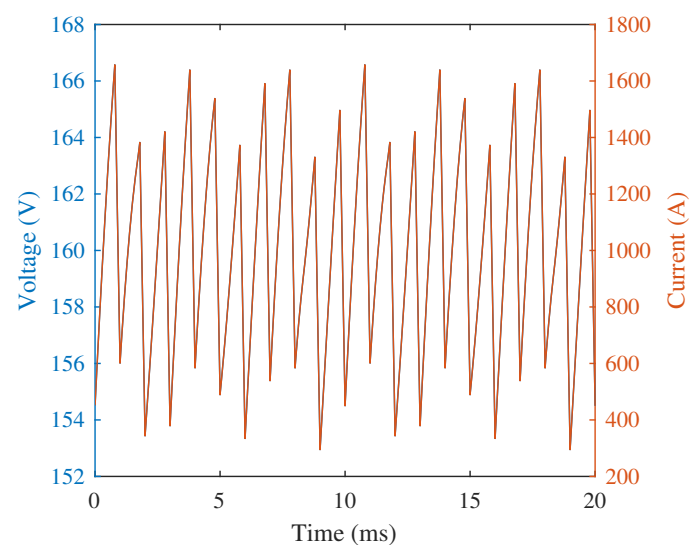

(a)

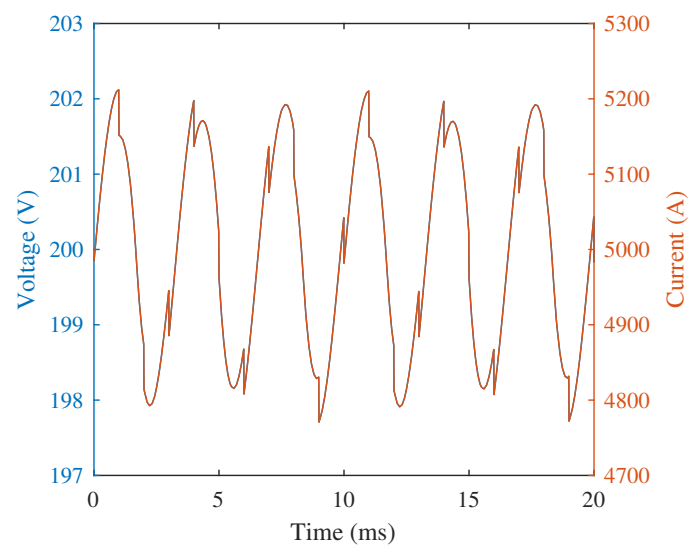

(b)

Fig. 11. Voltage and current waveforms of the buck rectifier at certain DC current levels, when $U_{A C}=150 \mathrm{~V}$. (a) $1000 \mathrm{~A}$. (b) $5000 \mathrm{~A}$.

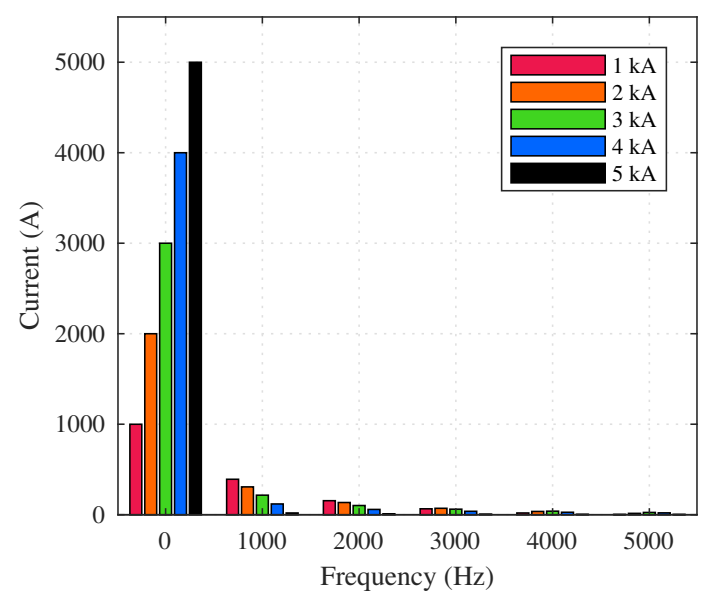

(a)

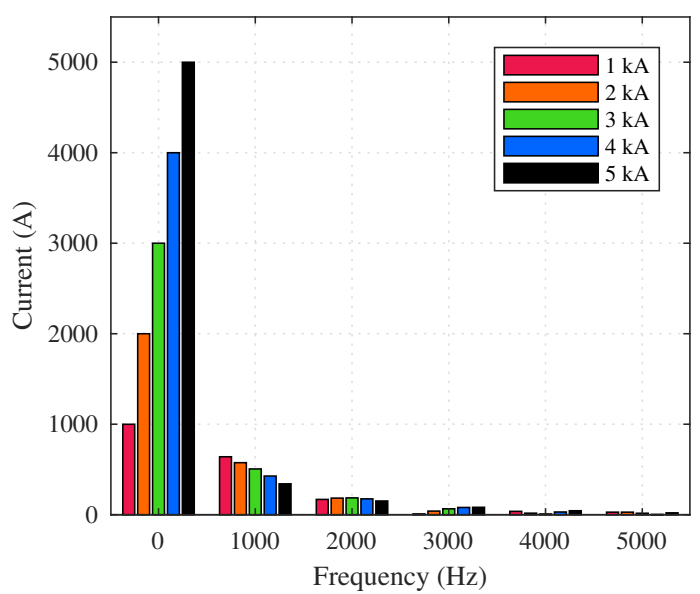

(b)

Fig. 12. Current frequency content with the buck rectifier at certain DC current levels. (a) $U_{A C}=150 \mathrm{~V}$. (b) $U_{A C}=175 \mathrm{~V}$.

consumption with the transistor converter is $1.5 \%$ higher than with the pure DC supply at the partial load of $1000 \mathrm{~A}$ and $0.9 \%$ higher at the full load. Obviously, the current quality and the output filter cost must be optimized for each case. The specific energy consumption with the transistor converter is presented as a function of DC current level and grid voltage in Fig. 14.

As the effect of AC voltage on the specific energy consumption of the elecrolyzer stack is almost insignificant, the specific energy consumption is practically only dependent on the DC current level. Eventually, the current quality and the stack efficiency are determined by the design of the rectifier output filter. However, a transistor-based converter has been shown to be able to achieve a high current quality with an output filter consisting of only an inductor with an inductance in the range of tens of microhenrys. 


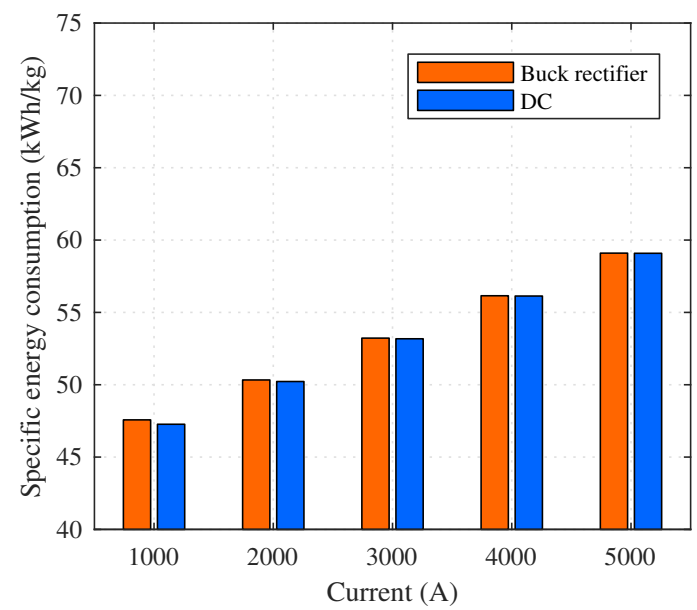

(a)

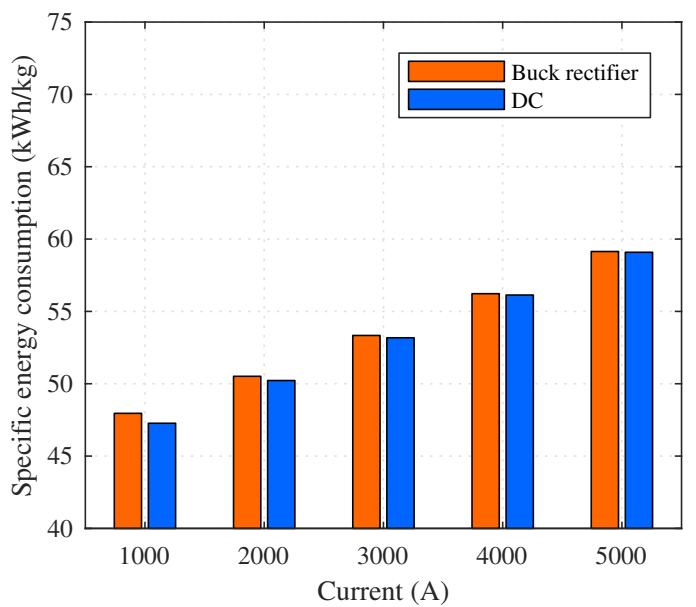

(b)

Fig. 13. Specific energy consumption of the electrolyzer supplied with the buck rectifier and pure DC at certain DC current levels. (a) $U_{A C}=150 \mathrm{~V}$. (b) $U_{A C}=175 \mathrm{~V}$.

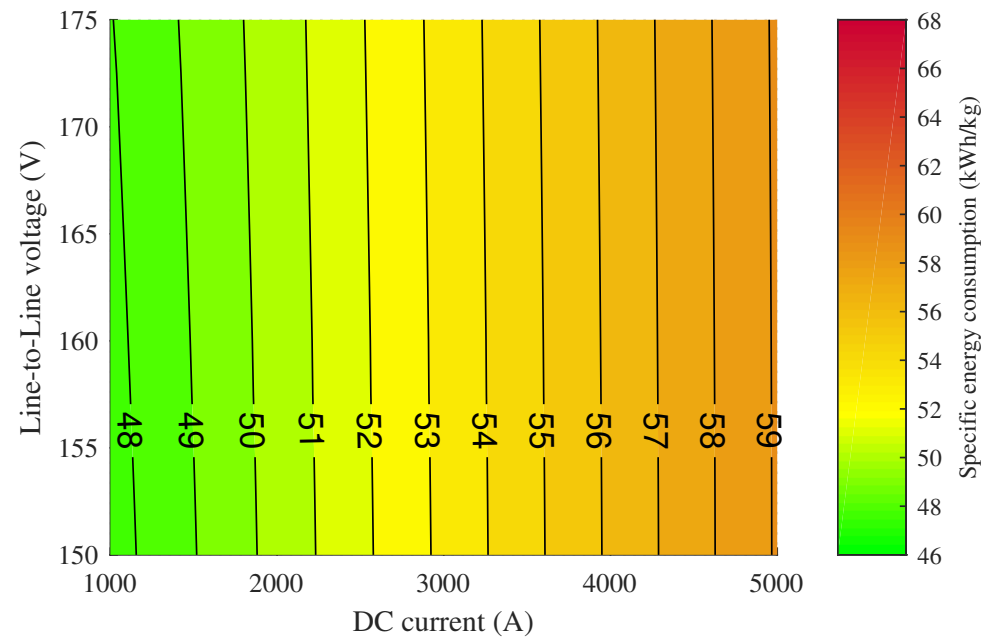

Fig. 14. Specific energy consumption of the electrolyzer as a function of DC current level and the line-to-line voltage of the transistor converter input.

\section{Comparison of the Topologies}

1) Current Quality: The amplitudes and frequencies of the dominating current harmonic components, found for 6- and 12-pulse thyristor bridges and a buck converter in the previous section, are collected to Table II. It can be seen that the harmonic amplitude exceeds the DC current level at partial loads with both studied thyristor bridge topologies. Further, 12-pulse bridge excites slightly lower harmonic amplitudes with higher frequency compared with the 6-pulse bride. However, only buck rectifier is able to offer current harmonics in the amplitude and frequency range allowed for fuel cells according to the literature [17]. The current quality of the buck rectifier could be further improved by selecting higher inductance output filter or applying parallel converter legs. 
TABLE II

Dominating Current Harmonic Components of the Studied Converter Topologies Compared with the Current Ripple Allowed for Fuel Cells in the Literature [17]. For the Buck Rectifier, a Constant DC Link Voltage Is Assumed.

\begin{tabular}{|c|c|c|c|c|c|c|c|}
\hline & \multirow{3}{*}{$\begin{array}{l}\text { Fuel cell } \\
\text { reference }\end{array}$} & \multicolumn{6}{|c|}{$U_{\mathrm{AC}}=150 \mathrm{~V}$} \\
\hline & & \multicolumn{2}{|c|}{ 6-pulse bridge } & \multicolumn{2}{|c|}{ 12-pulse bridge } & \multicolumn{2}{|c|}{ Buck rectifier } \\
\hline & & $1000 \mathrm{~A}$ & $5000 \mathrm{~A}$ & $1000 \mathrm{~A}$ & $5000 \mathrm{~A}$ & $1000 \mathrm{~A}$ & $5000 \mathrm{~A}$ \\
\hline Frequency $(\mathrm{Hz})$ & 1250 & 300 & 300 & 600 & 600 & 1000 & 1000 \\
\hline \multirow[t]{4}{*}{ Amplitude (\%) } & 5 & 168 & 31 & 144 & 22 & 39 & 0.4 \\
\hline & & \multicolumn{6}{|c|}{$U_{\mathrm{AC}}=175 \mathrm{~V}$} \\
\hline & \multirow{2}{*}{$\begin{array}{l}\text { Fuel cell } \\
\text { reference }\end{array}$} & \multicolumn{2}{|c|}{ 6-pulse bridge } & \multicolumn{2}{|c|}{ 12-pulse bridge } & \multicolumn{2}{|c|}{ Buck rectifier } \\
\hline & & $1000 \mathrm{~A}$ & $5000 \mathrm{~A}$ & $1000 \mathrm{~A}$ & $5000 \mathrm{~A}$ & $1000 \mathrm{~A}$ & $5000 \mathrm{~A}$ \\
\hline Frequency $(\mathrm{Hz})$ & 1250 & 300 & 300 & 600 & 600 & 1000 & 1000 \\
\hline Amplitude (\%) & 5 & 177 & 85 & 158 & 47 & 64 & 7 \\
\hline
\end{tabular}

2) Specific Energy Consumption: The differences in the resulting mean specific energy consumptions between the rectifier topologies originate from the DC current waveforms. An increase in current strongly contributes to the dissipated power because of the quadratic relationship of current in Ohmic heating. Therefore, the closer the stack $D C$ current waveform is to pure DC current, the lower the specific energy consumption of a water electrolyzer stack is. The resulting stack specific energy consumptions with the analyzed converter topologies are presented in Table III. With the 6-pulse thyristor rectifier, at the $150 \mathrm{~V}$ grid AC voltage, the mean stack specific energy consumption is $60.1 \mathrm{~kW} \mathrm{~h} \mathrm{~kg}^{-1}$ at the full load of $5000 \mathrm{~A}$ and $54.1 \mathrm{~kW} \mathrm{~h} \mathrm{~kg}^{-1}$ at the minimum load of $1000 \mathrm{~A}$. However, the stack specific energy consumption varies from $48.7 \mathrm{~kW} \mathrm{~h} \mathrm{~kg}^{-1}$ to $62.6 \mathrm{~kW} \mathrm{~h} \mathrm{~kg}^{-1}$ and from $44.3 \mathrm{~kW} \mathrm{~h} \mathrm{~kg}^{-1}$ to $58.2 \mathrm{~kW} \mathrm{~h} \mathrm{~kg}^{-1}$ at the full and minimum loads, respectively, when the specific energy is calculated point-by-point according to the stack voltage and stack current waveforms shown in Fig. 15. Additionally, as a result of the considerable $300 \mathrm{~Hz}$ AC current ripple, the instantaneous stack current reaches $0 \mathrm{~A}$ at DC current operating points $\leq 4000 \mathrm{~A}$. The minimum stack current as a function of electrolyzer load is illustrated for the three different topologies in Fig. 16.

In Fig. 15, the stack specific energy consumption with the 12-pulse rectifier varies from $52.9 \mathrm{~kW} \mathrm{~h} \mathrm{~kg}^{-1}$ to $62.5 \mathrm{~kW} \mathrm{~h} \mathrm{~kg}^{-1}$ and from $44.3 \mathrm{~kW} \mathrm{~h} \mathrm{~kg}^{-1}$ to $54.8 \mathrm{~kW} \mathrm{~h} \mathrm{~kg}^{-1}$ at the full and minimum loads, respectively. Because of the $600 \mathrm{~Hz}$ AC current ripple, the instantaneous stack current reaches $0 \mathrm{~A}$ at DC current operating points $\leq 3000 \mathrm{~A}$. With the transistor-based converter, the point-by-point stack specific energy consumption varies only slightly, and the instantaneous stack current remains above the $0 \mathrm{~A}$ level at all analyzed loads (1000 A to $5000 \mathrm{~A}$ ). If the current is not allowed to reach a zero value during operation, the buck rectifier can offer a significantly wider operating area than the thyristor rectifiers. This may be essential in the renewable energy applications, where electrolyzers are a key component in the electricity grid frequency control system. 
TABLE III

Specific Energy Consumption (SEC) with the Studied Converter Topologies Compared with Pure DC Supply.

\begin{tabular}{|c|c|c|c|c|c|c|c|c|}
\hline & & & \multicolumn{6}{|c|}{$U_{\mathrm{AC}}=150 \mathrm{~V}$} \\
\hline & \multicolumn{2}{|c|}{ DC } & \multicolumn{2}{|c|}{ 6-pulse bridge } & \multicolumn{2}{|c|}{ 12-pulse bridge } & \multicolumn{2}{|c|}{ Buck rectifier } \\
\hline & $1000 \mathrm{~A}$ & $5000 \mathrm{~A}$ & $1000 \mathrm{~A}$ & $5000 \mathrm{~A}$ & $1000 \mathrm{~A}$ & $5000 \mathrm{~A}$ & $1000 \mathrm{~A}$ & $5000 \mathrm{~A}$ \\
\hline SEC $\left(\mathrm{kW} \mathrm{h} \mathrm{kg}^{-1}\right)$ & 47.27 & 59.09 & 54.07 & 60.06 & 51.5 & 59.64 & 47.57 & 59.10 \\
\hline \multirow[t]{4}{*}{ SEC (\% of DC) } & 100 & 100 & 114.4 & 101.6 & 108.9 & 100.9 & 100.6 & 100.0 \\
\hline & & & \multicolumn{6}{|c|}{$U_{\mathrm{AC}}=175 \mathrm{~V}$} \\
\hline & \multicolumn{2}{|c|}{$\mathrm{DC}$} & \multicolumn{2}{|c|}{ 6-pulse bridge } & \multicolumn{2}{|c|}{ 12-pulse bridge } & \multicolumn{2}{|c|}{ Buck rectifier } \\
\hline & $1000 \mathrm{~A}$ & $5000 \mathrm{~A}$ & $1000 \mathrm{~A}$ & $5000 \mathrm{~A}$ & $1000 \mathrm{~A}$ & $5000 \mathrm{~A}$ & $1000 \mathrm{~A}$ & $5000 \mathrm{~A}$ \\
\hline SEC $\left(\mathrm{kW} \mathrm{h} \mathrm{kg}^{-1}\right)$ & 47.27 & 59.09 & 56.00 & 66.45 & 52.79 & 61.78 & 47.95 & 59.14 \\
\hline SEC (\% of DC) & 100 & 100 & 118.5 & 112.5 & 111.7 & 104.5 & 101.4 & 100.1 \\
\hline
\end{tabular}

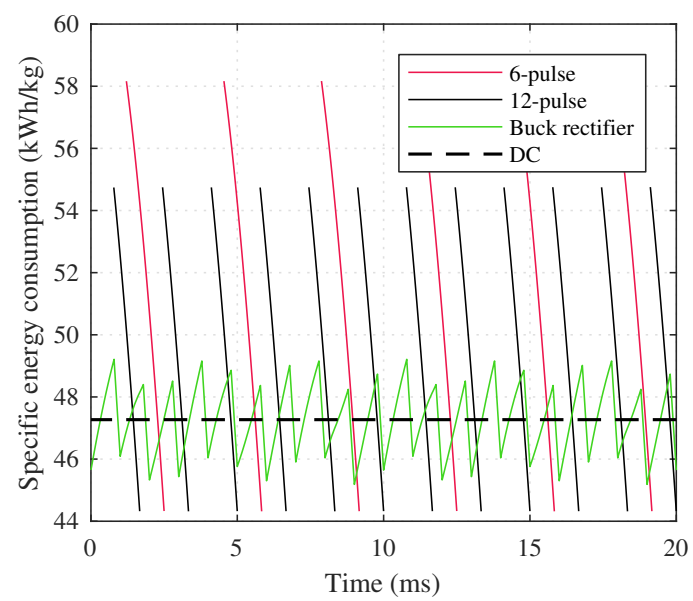

(a)

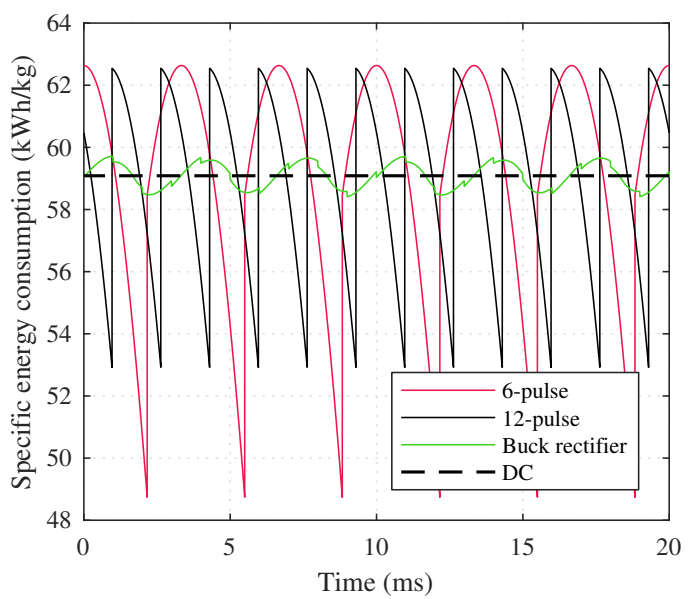

(b)

Fig. 15. Electrolyzer stack specific energy comparison for the three rectifier topologies and an ideal DC power supply when $U_{\mathrm{AC}}=150 \mathrm{~V}$. (a) 1000 A. (b) 5000 A.

3) Converter Losses: The internal losses of the converters are roughly estimated by the threshold voltage and onstate resistance of the semiconductor components. The component types are selected based on [24]. In the 6-pulse rectifier there are two thyristors connected in parallel to limit the current of the individual thyristor. The 12-pulse rectifier consists of two series-connected 6-pulse bridges. Therefore, the internal losses of the 12-pulse rectifier are approximately twice as high as the 6-pulse rectifier losses. In the buck rectifier there are two diodes in parallel in the 6-pulse diode rectifier bridge. On the DC side there are 12 transistors and six free-wheeling diodes in parallel. The switching on and off energies of the IGBT at the full load are $5 \mathrm{~mJ}$ and $16.5 \mathrm{~mJ}$. At the switching frequency of $1 \mathrm{kHz}$, the switching loss of a single transistor would be only $21.5 \mathrm{~W}$, which is insignificant in this study. Further, the losses of the inductive and capacitive filters are neglected in the study. The equivalent circuit parameters of the 


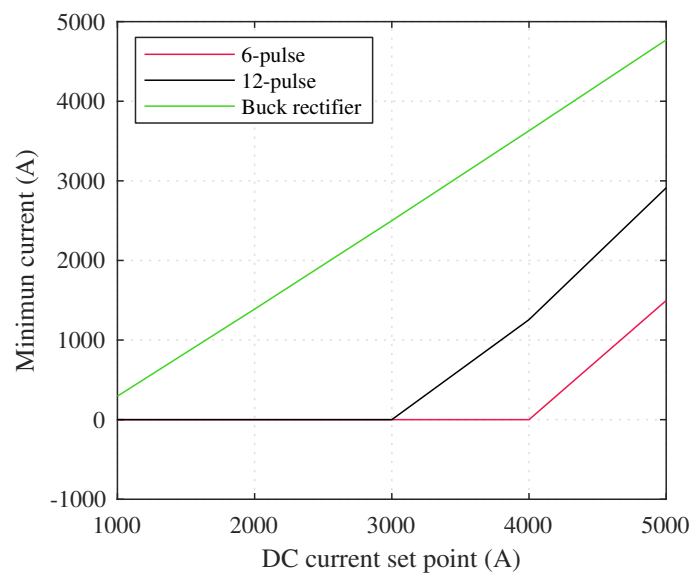

Fig. 16. Minimum current of a rectified waveform as a function of electrolyzer stack current set point when $U_{\mathrm{AC}}=150 \mathrm{~V}$.

components are given in Table IV.

TABLE IV

Equivalent Circuit Parameters of the Semiconductors for ConVerter Loss Estimation.

\begin{tabular}{lcc}
\hline \hline & Threshold voltage $(\mathrm{V})$ & Resistance $(\mathrm{m} \Omega)$ \\
\hline Diodes and thyristors (TZ800N12KOF) & 0.82 & 0.17 \\
IGBT transistors (FD600R06ME3) & 0.80 & 0.80 \\
\hline \hline
\end{tabular}

The loss power of each component is calculated separately based on the simulated current waveforms. The converter losses of the studied topologies are compared with each other at the stack current of $5000 \mathrm{~A}$ in Table V.

TABLE V

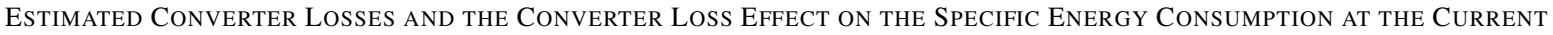
Level of 5000 A. The Stack Specific Energy Consumption in the Full Load Operation Is $60 \mathrm{~kW} \mathrm{~h} \mathrm{~kg}^{-1}$.

\begin{tabular}{lcccc}
\hline \hline & $\begin{array}{c}\text { Loss power } \\
(\mathrm{kW})\end{array}$ & $\begin{array}{c}\text { Converter specific energy } \\
\text { consumption }\left(\mathrm{kW} \mathrm{h} \mathrm{kg}^{-1}\right)\end{array}$ & $\begin{array}{c}\text { Minimum } \\
\text { current (A) }\end{array}$ & $\begin{array}{c}\text { Maximum } \\
\text { current (A) }\end{array}$ \\
\hline 6-pulse & 13 & 0.8 & 1497 & 6201 \\
12-pulse & 26 & 1.5 & 2912 & 6171 \\
Buck rectifier & 17 & 1.0 & 4771 & 5212 \\
\hline \hline
\end{tabular}

The converter losses, even at the full load, are less than $3 \%$ of the energy consumption of the electrolyzer stack, as the stack specific energy consumption is roughly $60 \mathrm{~kW} \mathrm{~h} \mathrm{~kg}^{-1}$ at the DC current level of $5000 \mathrm{~A}$. Therefore, the effect of current quality on the energy consumption of the stack is much more significant than the converter losses. Further, improving the power quality does not only affect the energy consumption of the stack, but the enhanced power quality may also have a positive effect on the lifetime of the electrolyzer stack. 
4) AC Voltage Selection: Finally, selection of the AC voltage level should be considered. In Section III, the simulated stack specific energy consumption remained invariable to the AC voltage only with the transistor-based converter topology. With both the 6- and 12-pulse thyristor rectifiers, the AC voltage has an impact on the resulting stack specific energy consumption (Table III). Therefore, a dependence on the AC voltage level hinders the specific energy consumption optimization task. Furthermore, selection of the AC voltage level may have to take into account the voltage degradation of individual electrolytic cells, especially if the AC voltage level cannot be controlled by the supply transformer with on-load tap changer. As the cells age, their voltage increases at a rate typically described in the range of $\mu \mathrm{Vh}^{-1}$ [9]. For alkaline water electrolyzers, stack lifetime values have been suggested to be in the range of $60000 \mathrm{~h}$ to $90000 \mathrm{~h}$ and cell voltage degradation rates $0.4 \mu \mathrm{V} \mathrm{h}^{-1}$ to $5.0 \mu \mathrm{V} \mathrm{h}^{-1}$ [9]. If the degradation rate of $5 \mu \mathrm{Vh}^{-1}$ is assumed to behave linearly for over $60000 \mathrm{~h}$ for the studied $1 \mathrm{MW}$ alkaline water electrolyzer (90 cells in series, $\left.U_{\text {stack }}=200 \mathrm{~V}\right)$, the increase in the stack voltage would be $27 \mathrm{~V}(+13.5 \%)$. The voltage degradation rate then determines a system design criterion for the water electrolysis plant: The selection of the AC voltage level should consider the stack voltage and its increase over the stack lifetime, and the capability of the water electrolysis plant to later meet its technical specifications as an increased stack voltage level results in a higher specific energy consumption or a lower electrolytic gas production rate.

A $25 \mathrm{~V}$ increase in the AC voltage would correspond to an $11 \%$ increase in the stack specific energy consumption with the 6-pulse thyristor rectifier and a $4 \%$ increase with the 12-pulse thyristor rectifier, when nominal operation at $5000 \mathrm{~A}$ is considered. With the transistor-based topology, this impact of the AC voltage increase on the increase in the stack specific energy consumption would be marginal or negligible. At the $150 \mathrm{~V}$ AC voltage level, the alkaline electrolyzer stack specific energy consumption with the transistor-based converter topology is $1.6 \%$ to $12.0 \%$ lower than with the 6-pulse thyristor rectifier depending on the stack DC current set point (5000 A to $1000 \mathrm{~A}$ ). Because of the increased $\mathrm{AC}$ voltage, especially the difference in specific energy consumption at the nominal current is emphasized (see Table III). Similar effect of the AC voltage on the stack specific energy consumption can be seen with the 12-pulse thyristor rectifier.

\section{CONCLUSION}

Water electrolyzers require DC power, and their operation depends on electric conditioning. In this paper, the specific energy consumption of a $1 \mathrm{MW}$ alkaline water electrolyzer $\left(U_{\text {stack }}=200 \mathrm{~V}, I_{\text {stack }}=5000 \mathrm{~A}\right)$ stack is simulated with three distinct industrial rectifier topologies: 1) a 6-pulse thyristor rectifier, a 12-pulse thyristor rectifier, and 3) a transistor-based converter. The resulting stack specific energy consumptions are compared against an ideal DC power supply.

It was found that the transistor-based converter topology can offer up to $14 \%$ lower stack specific energy consumption than the 6-pulse thyristor rectifier and up to $9 \%$ lower stack specific energy consumption than the 12-pulse thyristor rectifier in the studied current and voltage range. Furthermore, the selection of the AC voltage level may have a more adverse effect on the resulting stack specific energy consumption with the thyristor rectifier topologies. 
Future investigation on the specific energy analysis of water electrolyzers will focus on the Faraday efficiencythe ratio of the actual hydrogen production rate to the ideal hydrogen production rate-and how the harmonic components in the stack DC current may affect the hydrogen gas production. Furthermore, more detailed experimental work on the effect of load transients and current ripple on the electrochemical cell degradation phenomena used for water electrolysis is yet to be studied as most of the previous degradation studies have concentrated on fuel cell applications. 


\section{REFERENCES}

[1] P. Schmidt, W. Zittel, W. Weindorf, and T. Raksha, "Renewables in Transport 2050 Empowering a sustainable mobility future with zero Final Report," FVV, Tech. Rep., 2016.

[2] M. Fasihi, D. Bogdanov, and C. Breyer, "Techno-economic assessment of Power-to-Liquids (PtL) fuels production and global trading based on hybrid PV-wind power plants," in Proc. 10th Int. Renewable Energy Storage Conf. (IRES '16), Düsseldorf, Germany, Mar. 2016.

[3] G. Pleßmann, M. Erdmann, M. Hlusiak, and C. Breyer, "Global energy storage demand for a 100\% renewable electricity supply," Energy Procedia, vol. 46, pp. 22-31, 2014.

[4] J. Koponen, A. Kosonen, K. Huoman, J. Ahola, T. Ahonen, and V. Ruuskanen, "Specific energy consumption of PEM water electrolysers in atmospheric and pressurised conditions," in Proc. 18th European Conf. on Power Electron. and Applicat. (EPE '16-ECCE Europe), Karlsruhe, Germany, Sep. 2016.

[5] A. Kosonen, J. Koponen, K. Huoman, J. Ahola, V. Ruuskanen, T. Ahonen, and T. Graf, "Optimization strategies of PEM electrolyser as part of solar PV system," in Proc. 18th European Conf. on Power Electron. and Applicat. (EPE '16-ECCE Europe), Karlsruhe, Germany, Sep. 2016.

[6] J. Koponen, A. Kosonen, V. Ruuskanen, K. Huoman, M. Niemelä, and J. Ahola, "Control and energy efficiency of PEM water electrolyzers in renewable energy systems," Int. J. Hydrogen Energy, vol. 42, no. 50, pp. 29648-29660, Dec. 2017.

[7] M. Lehner, R. Tichler, H. Steinmüller, and M. Koppe, Power-to-gas: technology and business models. New York: Springer International Publishing, 2014.

[8] M. Götz, J. Lefebvre, F. Mörs, A. M. Koch, F. Graf, S. Bajohr, R. Reimert, and T. Kolb, "Renewable power-to-gas: A technological and economic review," Renewable Energy, vol. 85, pp. 1371-1390, Jan. 2016.

[9] L. Bertuccioli, A. Chan, D. Hart, F. Lehner, B. Madden, and E. Standen, Study on development of water electrolysis in the EU. Final report in fuel cells and hydrogen joint undertaking, Feb. 2014.

[10] M. Carmo, D. L. Fritz, J. Mergel, and D. Stolten, “A comprehensive review on PEM water electrolysis," Int. J. Hydrogen Energy, vol. 38, no. 12, pp. 4901-4934, Apr. 2013.

[11] A. Ursúa, P. Sanchis, and L. Marroyo, "Chapter 14 - electric conditioning and efficiency of hydrogen production systems and their integration with renewable energies," in Renewable Hydrogen Technologies, L. Gandía, G. Arzamendi, and P. Diéguez, Eds. Amsterdam: Elsevier, 2013, pp. 333-360.

[12] A. Ursúa, L. Marroyo, E. Gubía, L. M. Gandía, P. M. Diéguez, and P. Sanchis, "Influence of the power supply on the energy efficiency of an alkaline water electrolyser," Int. J. Hydrogen Energy, vol. 34, no. 8, pp. 3221-3233, May. 2009.

[13] A. Ursúa, I. S. Martín, and P. Sanchis, "Design of a programmable power supply to study the performance of an alkaline electrolyser under different operating conditions," in 2nd IEEE Int. Energy Conf. and Exhibition (ENERGYCON '12), Florence, Italy, Sep. 2012, pp. 259-264.

[14] R. S. Gemmen, "Analysis for the effect of inverter ripple current on fuel cell operating condition," J. Fluids Eng., vol. 125, no. 3, pp. 576-585, Jun. 2003.

[15] S. K. Mazumder, K. Acharya, C. L. Haynes, R. Williams, M. R. von Spakovsky, D. J. Nelson, D. F. Rancruel, J. Hartvigsen, and R. S. Gemmen, "Solid-oxide-fuel-cell performance and durability: resolution of the effects of power-conditioning systems and application loads," IEEE Trans. Power Electron., vol. 19, no. 5, pp. 1263-1278, Sep. 2004.

[16] E. Fontell, T. Kivisaari, N. Christiansen, J.-B. Hansen, and J. Pålsson, "Conceptual study of a $250 \mathrm{~kW}$ planar SOFC system for CHP application,” J. Power Sources, vol. 131, no. 1, pp. 49-56, May. 2004.

[17] P. Thounthong, B. Davat, S. Rael, and P. Sethakul, "Fuel cell high-power applications," IEEE Ind. Electron. Mag., vol. 3, no. 1, pp. 32-46, Mar. 2009.

[18] T. Sarkar and S. K. Mazumder, "Analysis of input current ripple and optimum filter capacitor for fuel-cell-based single-phase inverter," $J$. Fuel Cell Sci. Technol., vol. 12, no. 6, 2015.

[19] S. K. Pradhan, S. K. Mazumder, J. Hartvigsen, and M. Hollist, "Effects of Electrical Feedbacks on Planar Solid Oxide Fuel Cell," J. Fuel Cell Sci. Technol., vol. 4, no. 2, pp. 154-166, 2007.

[20] C. Rakousky, U. Reimer, K. Wippermann, S. Kuhri, M. Carmo, W. Lueke, and D. Stolten, "Polymer electrolyte membrane water electrolysis: Restraining degradation in the presence of fluctuating power," J. Power Sources, vol. 342, pp. 38-47, 2017.

[21] Z. Dobó and Árpád Bence Palotás, "Impact of the current fluctuation on the efficiency of alkaline water electrolysis," Int. J. Hydrogen Energy, vol. 42, no. 9, pp. 5649-5656, Mar. 2017. 
[22] J. Solanki, N. Fröhleke, J. Böcker, and P. Wallmeier, "Analysis, design and control of $1 \mathrm{MW}$, high power factor and high current rectifier system," in Proc. IEEE Energy Convers. Congress and Exposition (ECCE '12), Raleigh, USA, Sep. 2012, pp. 1725-1732.

[23] P. S. Maniscalco, V. Scaini, and W. E. Veerkamp, "Specifying DC chopper systems for electrochemical applications," IEEE Trans. Ind. Appl., vol. 37, no. 3, pp. 941-948, May/Jun. 2001.

[24] J. Solanki, N. Frohleke, J. Bocker, and P. Wallmeier, "Comparison of thyristor-rectifier with hybrid filter and chopper-rectifier for highpower, high-current application,” in Proc. PCIM Europe Conf., vol. 1, Nuremburg, Germany, May. 2013, pp. 1391-1398.

[25] J. R. Rodríguez, J. Pontt, C. Silva, E. P. Wiechmann, P. W. Hammond, F. W. Santucci, R. Álvarez, R. Musalem, S. Kouro, and P. Lezana, "Large current rectifiers: State of the art and future trends," IEEE Trans. Ind. Electron., vol. 52, no. 3, pp. 738-746, Jun. 2005.

[26] Y. Suh and P. K. Steimer, “Application of IGCT in high-power rectifiers,” IEEE Trans. Ind. Appl., vol. 45, no. 5, pp. 1628-1636, Sep. 2009.

[27] AEG Power Solutions. [Accessed: 23-May-2018]. [Online]. Available: https://www.aegps.com/en/products/customized-power-supplysystems/thyrobox-dc3/

[28] J. van der Merwe, K. Uren, G. van Schoor, and D. Bessarabov, "A study of the loss characteristics of a single cell PEM electrolyser for pure hydrogen production," in Proc. IEEE Int. Conf. Ind. Technol. (ICIT '13), Cape Town, South Africa, Feb. 2013, pp. 668-672.

[29] F. da Costa Lopes and E. H. Watanabe, "Experimental and theoretical development of a PEM electrolyzer model applied to energy storage systems," in Proc. Brazilian Power Electron. Conf. (COBEP ‘09), Bonito-Mato Grosso do Sul, Brazil, Sep. 2009, pp. 775-782.

[30] A. Ursúa and P. Sanchis, "Static-dynamic modelling of the electrical behaviour of a commercial advanced alkaline water electrolyser," Int. J. Hydrogen Energy, vol. 37, no. 24, pp. 18 598-18614, Dec. 2012.

[31] Ø. Ulleberg, "Modeling of advanced alkaline electrolyzers: a system simulation approach," Int. J. Hydrogen Energy, vol. 28, no. 1, pp. 21-33, Jan. 2003. 